\title{
MENUMBUHKAN JIWA KEWIRAUSAHAAN KEPALA MADRASAH DI MASA PANDEMI COVID-19
}

\author{
FURHATUL WAFIYAH \\ Pengawas Madrasah Kecamatan Pabelan Kabupaten Semarang \\ Kantor Kementerian Agama Kabupaten Semarang \\ Emaill: ef012wy@gmail.com
}

\begin{abstract}
ABSTRAK
Penelitian ini dilakukan untuk memberikan gambaran mengenai kompetensi kewirausahaan kepala madrasah di Kecamatam Pabelan Kabupaten Semarang di masa pandemi covid -19. Responden dari penelitian ini adalah 15 kepala madrash ibtidaiyah (MI) di Kecamatan Pabelan Kabuapten Semarang. Metode penelitian dengan menggunakan wawancara, angket/kuesioner, dan studi dokumen. Data penelitian dianalisis secara kuantitatif dan kualitatif Hasil penelitian menunjukkan bahwa: (1) Pada dimensi kreatif/inovatif ditunjukkan dengan usaha melengkapi sarana dan prasarana dan pendidikan dan penggunaan aplikasi online (2) pada dimensi kerja keras dipusatkan pada kerja team, pengembangan personel dan mutu pada hasil kerja; (3) pada dimensi motivasi ditunjukkan dengan kesiapan menghadapi tantangan, pengembangan madrasah dan pemberian penghargaan dan hukuman; (4) pada alternative solusi terbaik digambarkan dengan pembelajaran berbasis online (5) pada dimensi pengelolaan unit produksi/pelayanan tidak dapat terlaksana secara maksimal karena pandemi covid -19
\end{abstract}

Kata Kunci : kompetensi kewirausahaan, kepala madrasah , masa pandemi covid 19

\section{PENDAHULUAN}

Kondisi pandemi covid 19 yang dialami bangsa Indonesia berdampak pada semua bidang termasuk bidang pendidikan di madrasah. Pendidikan di madrasah harus tetap dilaksanakan. Kepala madrasah sebagai motor pelaksanaan pendidikan diharapkan mampu mensukseskan pendidikan dengan berbagai cara. Dalam kondisi darurat, kegiatan pembelajaran tidak bisa berjalan secara normal seperti biasanya, namun demikian siswa harus tetap mendapatkan layanan pendidikan dan pembelajaran. Pada masa darurat Covid-19, madrasah telah melaksanakan kegiatan pembelajaran di tengah kondisi darurat sesuai dengan kondisi dan kreatifitas masing-masing madrasah.Kreatifitas, inovasi dan ketrampilan kepala madrasah dalam mendesain kegiatan di madarasah terlebih dalam mempersiapkan sarana prasarana yang memadahi. Hal ini kepala madrasah dituntut mampu memaksimalkan kompetensinya walaupun dimasa pandemic covid 19. Kompetensi kepala sekolah/madrasah sangat menentukan keberhasilan pendidikan di suatu lembaga pendidikan , baik lembaga pendidikan milik pemerintah atau lembaga pendidikan yang diselenggarakan oleh masyarakat. Kompetensi kepala sekolah selain kompetensi pokok yang harus dimiliki banyak kompetensi lain yang sangat menentukan keberhasilan pendidikan.

Kecakapan dalam mengelola sumber daya manusia atau steakholder dan pengembangan dimensi-dimensi lainnya. Kepala sekolah sebagai leader harus mampu kemana arah lembaganya mencapai tujuan. Seluruh komponen dan sarana pendidikan idealnya kepala sekolah mampu mengelola dengan baik. Mengelola dan menyelenggarakn kegiatan sekolah, mengelola administrasi sekolah dengan baik, menyusun rencana strategias sebagai usaha pengembangan sekolah. Ketika kepala sekolah mampu memerankan tugas pokok dan fungsinya maka secara langsung akan mempengaruhi keberhasilan pendidikan.

Dalam usaha pengembangan sekolah, kepala sekolah dituntut untuk lebih ekstra peran dan waktunya untuk tercapainya tujuan pendidikan yang diembannya. Kepala sekolah sebagai unsur tertinggi dan menentuka kebijakan dan sangat berpengaruh terhadap kinerja guru, tenaga kependidikan. Selain itu kepala sekolah harus memiliki kepribadian dan sifat-sifat yang luhur serta memiliki kemampuan dan ketrampilan-ketrampilan untuk memimnpin 
sebuah lembaga pendidikan. Pengembangan kewirausahaan kepala sekolah/madrasah diantaranya kepala sekolah mampu menciptakan inovasi yang bermanfaat dan tepat, bekerja keras untuk mencapai keberhasilan sekolah/madrasah, memiliki motivasi yang kuat, pantang menyerah dan selalu mencari solusi terbaik dalam menghadapi kendala-kendala di madrasah dan memiliki naluri kewirausahaan dalm mengelola kegiatan produktif.,produksi/jasa sekolah/madrasah sebagai sumber belajar peserta didik (Permendiknas No. 13 Tahun 2007 )

Dalam mewujudkan tujuan lembaga pendidikan yang ideal faktor utamanya adalah bagaimana kepala sekolah menjalankan tugas pokok dan fungsinya. Kepala sekolah harus memiliki kompetensi khusus dibanding kompetensi guru.

Selain standar kualifikasi kepala sekolah juga harus memenuhi standar kompetensi. Dalam Permendiknas No. 1 Tahun 2007 disyaratkan 5 kompetensi yang harus dimiliki kepala sekolah. Lima kompetensi yang harus dikuasai oleh seorang kepala sekolah yaitu: kompetensi kepribadian, kompetensi manajerial, kompetensi kewirausahaan, kompetensi supervisi, dan kompetensi sosial. Kelima dimensi kompetensi tersebut dijabarkan ke dalam 33 kompetensi. Dari lima kompetensi pokok yang menjadi fokus penelitian adalah kompetensi kewirausahaan kepala sekolah.

Sedangkan Mutohar (2013:249) menjelaskan kepala sekolah sebagai entrepreneur harus mampu menerapkan prinsip-prinsip kewirausahaan sebagai berikut. Pertama, bertindak kreatif dan inovatif, kompetensi ini memiliki indikator, antara lain: a) menciptakan pembaruan, b merumuskan arti dan tujuan perubahan (inovasi) sekolah, c) menggunakan metode, teknik, dan proses perubahan sekolah, d) menciptakan dan memanfaatkan peluang, e) menciptakan program inovasi dan kreativitas, f) menciptakan keunggulan komparatif, dan g) mempromosikan sekolah. Kedua, memberdayakan potensi sekolah, yang meliputi: a) merencanakan program pemberdayaan potensi sekolah, b) melaksanakan kegiatan pemberdayaan potensi sekolah, c) menjalin kerja sama dengan masyarakat baik lembaga pemerintah maupun swasta. Ketiga,menumbuhkan jiwa kewirausahaan warga sekolah, yang meliputi: a) 31 menumbuhkan iklim yang mendorong kebebasan berpikir untuk menciptakan kreativitas dan inovasi, b) mendorong warga sekolah untuk melakukan eksperimentasi, prakarsa/keberanian moral untuk melakukan hal-hal baru, c) memberikan rewards atas hasilhasil kreativitas warga sekolah, d) menumbuhkan dan mengembangkan jiwa kewirausahaan warga sekolah.

Berdasarkan fenomena diatas Madrasah Ibtidaiyah (MI) Kecamatan Pabelan Kabupaten Semarang menunjukkan bahwa 1). Kepala Madrasah Ibtidaiyah Kecamatan Pabelan mempunyai potensi untuk mengembangkan kreatifitas, inovasi dalam pengembangan madrasah 2) Usia kepala madrasah banyak yang masih muda di bawah 45 tahun.. Idealnya kompetensi kewirausahaan yang dimilik kepala madrasah bagus dan maksimal. Namun fenomena yang terjadi di MI Kecamatan Pabelan Kabupaten Semarang kompetensi kewirausahaan masih rendah atau belum bagus.

Permasalahan yang akan dibahas pada penelitian ini adalah: Bagaimana gambaran kompetensi kewirausahaan kepala madrasah di Kecmatan Pabelan Kabupaten Semarang di masa pandemic covid 19? Bagaiamana bentuk inovasi yang diciptakan kepala madrasah di Kecamatan Pabelan Kabupaten Semarang di masa pandemic covid 19? Adapaun tujuan penelitian adalah untuk mendeskripsikan dan menganalisis usaha-usaha yang dilakukan kepala madrasah di masa pandemic covid 19 , kendala-kendala apa saja yang menghambat kreatifitas kepala madrasah di kecamatan Pabelan Kabupaten Semarang di masa pandemic covid 19. .

\section{METODE PENELITIAN}

Metode penelitian yang digunakan dalam penelitian ini adalah pendekatan kualitatif dengan menggunakan jenis penelitian lapangan (field research) dengan deskripif kualitatif. 7Penelitian kualitatif atau qualitative research merupakan jenis penelitian yang menghasilkan penemuan-penemuan yang tidak dapat dicapai dengan menggunakan prosedur-prosedur 
statistik atau dengan cara kuantitatif lainnya. Menurut Strauss dan Corbin (2007:1), penelitian kualitatif ini merupakan penelitian yang dapat digunakan untuk meneliti kehidupan masyarakat, sejarah, tingkah laku, fungsionalisasi organisasi, gerakan sosial, atau hubungan kekerabatan. Sementara itu, menurut Arikunto. (2005) bahwa penelitian kualitatif merupakan prosedur penelitian yang mampu menghasilkan data deskriptif berupa ucapan, tulisan, dan perilaku dari orang-orang yang diamati. Melalui penelitian kualitatif ini dimungkinkan ntuk diperoleh pemahaman tentang kenyataan melalui proses berpikir induktif.

\section{HASIL DAN PEMBAHASAN}

Gambaran kompetensi kewirausahaan kepala madrasah ibtidaiyah(MI) Kecamatan Pabelan Kabupaten Semarang di masa pandemic covid 19 dapat diwujudkan dengan baik sesuai kondisi masing-masing madrasah, diketahui melalui hasil pemantauan dengan instrument dimensi kewirausahaan. Kondisi kepala madrasah di Kecamatan Pabelan dapat dilihat dari table berikut:

Tabel. 1 Data Kepala Madrasah Ibtidaiyah Kecamatan Pabelan Data GTT/PTT Kecamatan pabelan Tahun 2021

\begin{tabular}{|c|c|c|c|c|}
\hline $\begin{array}{l}\mathbf{N} \\
\mathbf{O} \\
\end{array}$ & NAMA MADRASAH & $\begin{array}{c}\text { NAMA } \\
\text { KEPALA }\end{array}$ & $\begin{array}{c}\text { TEMPAT/ } \\
\text { TGL.LAHIR } \\
\end{array}$ & $\begin{array}{c}\mathrm{KE} \\
\mathbf{T} \\
\end{array}$ \\
\hline 1 & $\begin{array}{l}\text { MI Al Khoiriyah Semowo } \\
02\end{array}$ & $\begin{array}{l}\text { Dra Siti } \\
\text { Markamah }\end{array}$ & $\begin{array}{l}\text { Kab.Semarang, 18-01- } \\
1967\end{array}$ & \\
\hline 2 & MI AL-Ittihad Semowo 01 & $\begin{array}{l}\text { Avif Nuravifah. } \\
\text { SS }\end{array}$ & $\begin{array}{l}\text { Indramayu, } 20-08- \\
1981\end{array}$ & \\
\hline 3 & $\begin{array}{l}\text { MI Bustanul Mutaalimin } \\
\text { Bejaten }\end{array}$ & $\begin{array}{l}\text { Anik Zulichah } \\
\text { S.Pd.I }\end{array}$ & $\begin{array}{l}\text { Magelang, 25-05- } \\
1970\end{array}$ & \\
\hline 4 & $\begin{array}{l}\text { MI Falahul Mukminin } 01 \\
\text { Padaan }\end{array}$ & $\begin{array}{l}\text { Emi Fitriyati } \\
\text { S.Pd.I }\end{array}$ & $\begin{array}{l}\text { Kab.Semarang, } 2712 \\
-1974\end{array}$ & \\
\hline 5 & $\begin{array}{l}\text { MI Falahul Mukminin } 02 \\
\text { Padaan }\end{array}$ & $\begin{array}{l}\text { Umi Ivayatuz Z.N } \\
\text { S.Pd }\end{array}$ & $\begin{array}{l}\text { Kab.Semarang, 28-03- } \\
1992\end{array}$ & \\
\hline 6 & $\begin{array}{l}\text { MI Miftahul Falah } \\
\text { Kadirejo } 01\end{array}$ & Nur Zaini, S Pd. I & $\begin{array}{l}\text { Kab.Semarang, 21-08- } \\
1978\end{array}$ & \\
\hline 7 & $\begin{array}{l}\text { MI Miftahul Ulum } \\
\text { Kadirejo } 02\end{array}$ & Widodo S.Pd.I & $\begin{array}{l}\text { Kab.Semarang, 16-04- } \\
1981\end{array}$ & \\
\hline 8 & $\begin{array}{l}\text { MI Miftahul Huda } \\
\text { Sumberejo } 01\end{array}$ & $\begin{array}{l}\text { Nur Khasanah, } \\
\text { S.Pd.I }\end{array}$ & $\begin{array}{l}\text { Kab.Semarang, } 08 \text { - } \\
09-1877\end{array}$ & \\
\hline 9 & $\begin{array}{l}\text { MI Miftahun Najihin } \\
\text { Kauman Lor }\end{array}$ & $\begin{array}{l}\text { Taufik Ismail } \\
\text { S.Pd.I }\end{array}$ & $\begin{array}{l}\text { Kab.Semarang, 02- } \\
\text { 05-1976 }\end{array}$ & \\
\hline 10 & $\begin{array}{l}\text { MI Muhammadiyah } \\
\text { Tukang }\end{array}$ & Budiyanto S.Pd.I & $\begin{array}{l}\text { Kab.Semarang, 11-07- } \\
1074\end{array}$ & \\
\hline 11 & MI Nurul Azhar Terban & Prayitno S.Pd.I & $\begin{array}{l}\text { Kab.Semarang, } 05 \text { - } \\
\text { 11-1961 }\end{array}$ & \\
\hline 12 & $\begin{array}{l}\text { MI Nurul Huda } \\
\text { Sumberejo } 02\end{array}$ & $\begin{array}{l}\text { M. Muhroni } \\
\text { S.Pd.I }\end{array}$ & $\begin{array}{l}\text { Kab.Semarang, 08-11- } \\
1977\end{array}$ & \\
\hline 13 & MI Pabelan & $\begin{array}{l}\text { Abdul Muid, } \\
\text { S.Pd.I }\end{array}$ & $\begin{array}{l}\text { Kab.Semarang, 09-10- } \\
1981\end{array}$ & \\
\hline 14 & $\begin{array}{l}\text { MI Tarbiyatul Aulad } \\
\text { Giling }\end{array}$ & Mahasin, S.Pd.I & $\begin{array}{l}\text { Kab.Semarang, 04-07- } \\
1972\end{array}$ & \\
\hline 15 & $\begin{array}{l}\text { MI Tarbiyatul Ulum } \\
\text { Jembrak }\end{array}$ & Dra. Husnul Dwi & $\begin{array}{l}\text { Kab.Semarang, 28- } \\
\text { 02-1968 }\end{array}$ & \\
\hline
\end{tabular}

Dari data tersebut dapat disimpulkan bahwa rata-rata usia kepala madrasah ibtidaiyah(MI) Kecamatan Pabelan masih muda dan masa produktif dalam bekerja. Di usia 
yang masih produktif dalam bekerja terutama pada pengelolaan madrasah, pengelolaan kessiswaan dan sarana prsarana di masa pandemic covid-19 ini diharapkan mampu mengembangkan potensi dan kreatifitas serta inovasinya dalam melaksankan tugas pokok dan fungsinya.

Masa pandemic covid 19 yang melanda negara kita Indonesia mengharuskan kita untuk menghadapinya dengan tepat dan usaha pencegahan yang maksimal. Terlebih di dunia pendidikan, belajar harus tetap jalan , siswa harus bisa belajar, guru harus bisa memberikan pelajaran walaupun dalam kondisi darurat. Kondis Kecamatan Pabelan disaat pelaksanaan penelitian dapat terlihat pada gambar berikut:

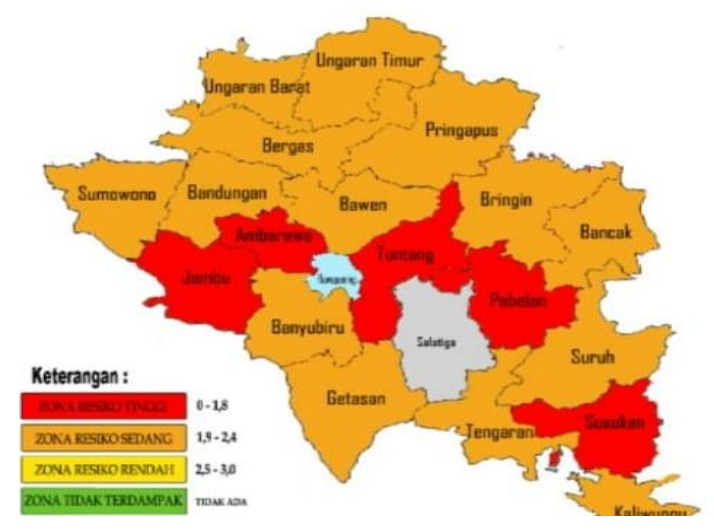

\section{Gambar 1. Peta Zonasi Penyebaran Covid 19 Kabupaten Semarang @semarangkab.go.id}

Peta tersebut menggambarkan kondisi penyebaran covid 19 yang terjadi di Kabupaten Semarang,dan Kecamatan Pabelan termasuk dari 5 kecamatan yang menduduki zona merah selama 28 minggu secara berturut-turut. Hal ini menyebabkan seluruh sekolah/madrasah melaksanakan kegiatan dan pembelajaran secara daring. Kepala madrasah dan guru harus mampu mendesain pembelajaran berbasis online walaupun dengan keterbatan sarana prasarana. Kreatifitas dan inovasi pembelajaran sangat diperlukan dengan penerapan protokol kesehatan yang lebih ketat.

Kreatifitas dan inovasi yang dilakukan kepala madrasah selama pandemic covid 19 dapat diuraikan sebagai berikut : Pada dimensi mampu menciptakan inovasi yang bermanfaat dan tepat diwujudkan dengan tersusunnya kurikulum darurat covid yang diberlakukan di satuan pendidikan. Kurikulum darurat covid ini tersusun berdasarkan Surat Keputusan Direktur Jenderal Pendidikan Islam Nomor 2791 Tahun 2020, tertanggal 18 Mei 2020. dan menciptkan inowasi pelaksanaan penerimaan siswa baru (PPDB) berbasis online, dengan menggunakan goole form.

Menciptakan inovasi yang tepat di masa pandemi ini sangat mendesak untuk dilaksanakan. Menurut Subadi (2011) target atau sasaran inovasi yang dapat dilaksanakan oleh kepala sekolah bisa menyangkut bidang-bidang kurikulum, sarana dan prasarana, pengelolaan keuangan, strategi pembelajaran, pengelolaan siswa, tenaga guru, hubungan masyarakat.

Inovasi di bidang kurikulum kepala madrasah dalam hal ini dapat melakukan inovasi/pembaharuan dengan memodifikasi kurikulum yang ada dengan kurikulum darurat yang berisi tentang standar operasional pembelajaran di masa pandemic covid 19 dengan mendesain jadual pelajaran, materi dan pembiasaan menjaga kesehatan dan mematuhi protokol kesehatan, sehingga guru dan siswa terbiasa hidup sehat.

Inovasi bidang pengelolaan sarana dan prasarana dapat dilakukan antara pihak sekolah dengan orang tua siswa (komite sekolah) dalam pembangunan gedung, dan sarana protokol kesehatan(tempat cuci tangan dan perlengkapannya). Penerapan protokol keshatan di madrasah sangat diprioritaskan dengan pembiasaan perilaku hidup sehat dengan mematuhi 
anjuran pemerintah dengan pembiasaan $3 \mathrm{M}$ ( Mencuci tangan dengan sabun, menjag jarak dan menjauhi kerumunan).

Inovasi bidang pengelolaan leuangan dengan di madrasah ibtidaiyah kecamatan Pabelan sudah menginput pengelolaan keuangan BOS dengan aplikasi E-RKAM dengan diawali dengan analisis EDM (Evaluasi Diri Madrasah). Pada aplikasi ini semua transaksi keuangan terekam dan laporan pertanggungjawaban dengan system online dengan system upload bukti pembelanjaan. Pengelolaan keuangan ini dengan prinsip open management. Untuk menunjang pembeljaran online, madrasah memberikan subsidi kouta kepada siswa atau orang tua siswa dengan alokasi dana BOS.

Sedangkan inovasi bidang strategi pembelajaran dalam hal ini kepala sekolah dapat menghimbau kepala para guru agar menciptakan inovasi strategi pembelajaran yang dilaksanakannya. Pada masa pandemic ini model pembelajaran di madrasah belum semua madarsah menggunakan aplikasi E-Learning baru sebatas pemanfaatan aplikasi WA group masing-masing kelas.

Dalam inovasi bidang pengelolaan siswa. Dalam hal ini dapat dimulai dari penerimaan siswa baru, yaitu melalui seleksi yang matang dan tidak asal terima, kemudian digodok melalui proses belajar mengajar yang berkualitas sehingga menghasilkan lulusan (output) yang berkualitas pula. Di masa pandemic, madarsah ibtidaiyah di Kecamatan Pabelan menggunakan aplikasi online. Untuk pengelolaan kesiswaan kepala madrasah telah menggunakan aplikasi Emis. Seluruh adata siswa dapat di update di aplikasi tersebut.

Selanjutntya inovasi bidang pengelolaan tenaga guru dan kependidikan dalam hal ini kepala sekolah dapat melakukan perekrutan tenaga guru atau kependidikan lainnya secara profesional melalui pembinaan serta pelatihan yang ada. Pengelolaan guru dan lembaga menggunakan aplikasi simpatika Untuk memonitoring kegiatan guru dan tenaga kependidikan kepala madrasah menggunakan aplikasi goole form sebagai laporan kegiatan mingguan . Laporan ini berjenjang dari guru melaporkan kegiatan hariannya kepada kepala maaadrasah, kepala madrasah melaporkannya kepada pengawas dan selanjutnya ke institusi kementerian agama kabupaten Semarang Dengan demikian profesionalisasi guru di masa pandemic 19 tentu akan membantu kepala sekolah dalam melangsungkan proses inovasi di sekolah tersebut.

Sedangkan inovasi bidang hubungan masyarakat dalam hal ini kepala sekolah dapat melakukan pelibatan orang tua siswa dalam menjalankan keputusan lembaga, sehingga stakeholders muncul rasa "mutual support" dan pada akhirnya memberikan dukungan dalam melaksanakan keputusan yang telah dicapai bersama bahkan bertanggungjawab atas maju tidaknya sekolah..

Dari uraian tersebut bahwa kompetensi kewirausahaan pada dimensi mampu menciptakan inovasi yang diciptakan kepala madrasah mencangkup beberapa aspek sehingga dalam kondisi pandemic covid-19, pengelolaan madrasah dapat berjalan sesuai harapan.

Menurut Reni Oktavia (2014: 601) kerja keras yang dilakukan oleh kepala sekolah dapat menumbuhkan etos kerja yang kuat atau tinggi. Etos kerja yang tinggi dari kepala sekolah akan memberikan efek yang positif bagi guru dan karyawan. Kepala sekolah dapat memberikan teladan dengan berusaha sepenuh hati, sekuat tenaga, dan keyakinan yang sungguh-sungguh untuk mencapai hasil yang optimal. Kepala sekolah perlu bekerja keras untuk mewujudkan keberhasilan sekolah, karena tidak akan ada kesuksesan tanpa adanya upaya kerja keras. Pada dimensi bekerja keras untuk mencapai keberhasilan sekolah, kepala madrasah telah menunjukkan hasil kerjanya dalam menyusun program madrasah , pengelolaan madrasah dengan melibatkan kerja tim (teamwork) dengan etos kerja tinggi yang didasari dengan keikhlasan. Dalam menyusun program kerja di masa pandemi ini, kepala madrasah menggunakan aplikasi E.RKAM yang tertuang melalui analisis Evaluasi Diri Madrasah(EDM) 
Menurut Gibson dalam Winardi (2004:4) menarik sejumlah kesimpulan tentang motivasi yaitu motivasi berkaitan dengan perilaku dan kinerja serta motivasi yang berbentuk pengarahan untuk mencapai tujuan.

Berdasarkan pendapat tersebut, kepala madrasah menunjukkan nya dengan terlaksananya kegiatan madrasah sesuai dengan tugas pokok fungsinya sebagai kepala madrasah. Dalam hal ini kepala madrasah selalu memberikan semangat dan motivasi kepada guru dalam melaksankan pembelajaran secara daring yang mana kegiatan pembelajaran ini dapat menyita waktu yang banyak. Ini dapat ditunjukkan ketika memberi tugas daring, oaring tua atau siswa mengirimnya tidak tepat waktu bahkan sampai malam baru terkirim, tergantung akses internet yang dimiliki. Maka untuk menguatkan motivasi tersebut kepala madrasah memberikan reword kepada guru selaku bawahannya. Menurut Barnawi dan Mohammad Arifin (2012: 125) sebagai motivator kepala sekolah sekolah harus mampu menjaga motivasi kerja guru dan karyawannya. Motivasi dapat ditumbuhkan melalui pengaturan lingkungan fisik, pengaturan suasana kerja, dan penerapan reward and punishment

Dimensi kewirausahaan Pantang menyerah dan selalu mencari solusi terbaik dalam menghadapi kendala yang dihadapi sekolah dengan patokan: kepala sekolah mampu menginternalisasikan jiwa wirausaha di kehidupan nyata berupa: optimisme, pantang menyerah, dan berpikir alternatif. Dalam dimensi ini kepala madrasah dalam kondisi pandemi, segala bentuk kegiatan tatap muka ditiadakan menuntut semua steakholder berfikir alternative agar pembelajaran tetap berjalan, hal ini dibuktikan dengan pengalihan anggaran BOS yang jumlah lebih dari $50 \%$ dari total anggaran BOS yang diperoleh masing -masing madrasah. Hal tersebut sejalan dengan hasil penelitian Oktavia (2014: 603) kepala sekolah harus mampu mengelola dan memecahkan masalah yang terjadi di sekolah serta mampu mencerminkan sikap pantang menyerah dalam meningkatkan prestasi sekolah maupun prestasi kerja

Memiliki naluri kewirausahaan dalam mengelola kegiatan produksi/jasa sekolah sebagai sumber belajar peserta didik dengan patokan: a) kepala sekolah menginternalisasikan jiwa wirausaha di kehidupan nyata berupa: pengembangan unit usaha, pengelolaan unit usaha, dan pemanfaatan unit usaha sebagai sumber belajar, b) kepala sekolah memiliki keberanian mengambil risiko.

Dari uraian tersebut Kepala Madrasah harus mampu menjaga dan meningkatkan kualitas sekolah. Ketika kualitas madrasah baik, masyarakat, khususnya orang tua akan bersedia berperan aktif di sekolah, karena yakin anaknya akan mendapat layanan pendidikan yang baik. Di sanalah pentingnya pribadi wirausaha kepala sekolah, untuk mencari jalan meningkatkan kualitas sekolah agar masyarakat dan orang tua menaruh kepercayaan terhadap produktivitas sekolah, dan mau berpartisipasi dalam berbagai program dan kegiatan sekolah (Mulyasa, 2011: 194). Menurut Mutohar (2013: 204) proses kreativitas merupakan syarat utama munculnya kemampuan entrepreneurship. Proses kreativitas merupakan proses pembangkitan ide, yang mana insividu maupun kelompok berproses menghasilkan sesuatu yang baru dengan lebih efektif dan efisien dalam sistem persekolahan. Di masa pandemic ini kegiatan produksi tidak bisa dilaksanakan di madrasah karena tidak dapat melaksanakan kegiatan secara tatap muka. Segala bentuk wira usaha di madrasah terhambat dengan kondisi pandemic 19 ini .

Usaha yang dapat dilakasanakan dimasa pandemic covid 19 ini kepala madrasah sudah dapat melaksanakan tugasnya dengan baik, dan di kompenetensi kewirausahaan dapat terlihat dari table berikut:

Tabel.3 Hasil Kewirausahaan Kepala Madrasah di Masa Pandemi Covid 19

\begin{tabular}{|c|c|c|c|}
\hline NO & $\begin{array}{c}\text { Dimensi } \\
\text { Kewirausahaan }\end{array}$ & Usaha yang dilakukan & Hasil \\
\hline 1 & $\begin{array}{lr}\text { mampu } & \text { menciptakan } \\
\text { inovasi } & \text { yang }\end{array}$ & $\begin{array}{l}\text { Menyusun Kurikulum darurat, } \\
\text { PPDB online gogle form dan }\end{array}$ & Baik \\
\hline
\end{tabular}




\begin{tabular}{|c|l|l|l|}
\hline & bermanfaat dan tepat & $\begin{array}{l}\text { pembelajaran dengan aplikasi E- } \\
\text { learning group WA, dan } \\
\text { aplikasi Emis, Simpatika, E } \\
\text { RKAM }\end{array}$ & \\
\hline 2 & $\begin{array}{l}\text { bekerja keras untuk } \\
\text { mencapai keberhasilan } \\
\text { sekolah, }\end{array}$ & $\begin{array}{l}\text { Mengadakan pemenuhan sarana } \\
\text { prasarana pendukung protokol } \\
\text { kesehatan.Semua madrasah telah } \\
\text { memiliki tempat cuci tangan } \\
\text { yang standar kesehatan }\end{array}$ & baik \\
\hline 3 & $\begin{array}{l}\text { memiliki motivasi yang } \\
\text { kuat }\end{array}$ & $\begin{array}{l}\text { Memberikan reward dan teguran } \\
\text { melaui monitoring laporan } \\
\text { mingguan dengan goole form }\end{array}$ & baik \\
\hline 4 & $\begin{array}{l}\text { Pantang menyerah dan } \\
\text { selalu mencari solusi } \\
\text { terbaik dalam } \\
\text { menghadapi kendala } \\
\text { yang dihadapi sekolah }\end{array}$ & $\begin{array}{l}\text { Pemenuhan pembelajaran daring } \\
\text { dengan prioritas pemenuhan } \\
\text { anggaran dari BOS, } \\
\text { menindaklanjuti kendala - } \\
\text { kendala selama PBM dengan } \\
\text { menambah kapasitas jaringan } \\
\text { hternret }\end{array}$ & baik \\
\hline $\begin{array}{l}\text { memiliki naluri } \\
\text { kewirausahaan dalm } \\
\text { mengelola kegiatan } \\
\text { produktif.,produksi/jasa } \\
\text { sekolah/madrasah } \\
\text { sebagai sumber belajar } \\
\text { peserta didik }\end{array}$ & $\begin{array}{l}\text { Pemberdayaan kegiatan produk } \\
\text { dengan memberi subsidi kouta } \\
\text { internet kepada siswa/orang tua } \\
\text { untuk menunjang pembelajaran } \\
\text { online. baik }\end{array}$ & \\
\hline
\end{tabular}

\section{KESIMPULAN}

Kapala madrasah harus dapat menciptakan dan mengembangkan inovasinya sehingga ia akan mampu mengatasi hambatan-hambatan yang ada dan mampu mengubah hambatan itu menjadi tantangan. Keberhasilan madrasah sebagai organisasi pembelajar yang efektif pada dasarnya tidak mudah lebih-lebih mengelola lembaga pendidikan yang tujuannya akan menghasilkan sumber daya manusia yang bermutu dan handal dalam kondisi apapun, terlebih di masa pandemic ciovid 19 ini.

Kepala madrasah harus belajar menguasai tehnologi dan masa digital ini kepala madrasah dan guru harus mampu mengoperasikan aplikasi -aplikasi yang menunjang pembelajaran. Madrasah sebagai organisasi dapat sukses dalam melaksanakan kegiatannya dibutuhkan kerja tim, pemberdayaan guru dan tenaga pendidikan sanga dibutuhkan untuk mencapai tujuan madrasah yang ingin dicapai.

\section{DAFTAR PUSTAKA}

Arikunto. (2005). Manajemen Penelitian. Jakarta: Rineka Cipta

Barnawi \& Mohammad Arifin. (2012). Schoolpreneurship: Membangkitkan Jiwa dan Sikap Kewirausahaan Siswa. Yogyakarta: Ar-Ruzz Media.

Kemendiknas. (2007). Peraturan Menteri Pendidikan Nasional No. 13 Tahun 2007 Tentang Standar Kepala Sekolah/Madrasah.

Mulyasa. (2011). Manajemen dan Kepemimpinan Kepala Sekolah. Jakarta: Bumi Aksara. Mutohar (2013) Jurnal kajian teori dan praktek kependidikan FIP Universitas Malang 21 Reni Oktavia. (2014). Kompetensi Kewirausahaan Kepala Sekolah pada Sekolah Menengah Pertama Negeri di Kecamatan Hiliran Gumanti Kabupaten Solok. Diakses dari: ejournal.unp.ac.id/index.php/bahana/article/download/ 3803/3036.

Subadi, M. Si. “Inovasi Pendidikan” (Surakarta: FKIP UMS, 2011), 